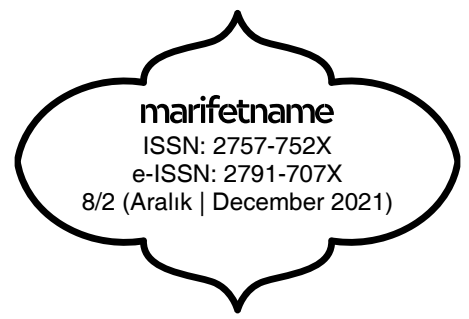

Ahmed Mahmûd Subhî'nin Hayatı, Eserleri ve İslam Düşüncesine Katkısı

Ahmad Mahmoud Subhi's Life, Works and Contribution to Islamic Thought

\title{
İran KARADENIZ
}

Arş. Gör., Recep Tayyip Erdoğan Üniversitesi İlahiyat Fakültesi, İslam Felsefesi Bölümü, Rize/Türkiye

Res. Assit., Recep Tayyip Erdogan University Faculty of Divinity, Department of Islamic Philosophy, Rize/Turkey

irfan.karadeniz@erdogan.edu.tr | orcid.org/ 0000-0003-2126-8973

DOI: $10.47425 /$ marifetname.vi.988846

Makale Bilgisi | Article Information

Makale Türü | Article Type: Araştırma Makalesi | Research Article

Geliş Tarihi | Received: 31 Ağustos / August 2021

Kabul Tarihi | Accepted: 15 Kasım / November2021

Yayın Tarihi | Published: 30 Aralık / December 2021

\section{Atıf $\mid$ Cite as}

Karadeniz, İrfan. "Ahmed Mahmûd Subhînin Hayatı, Eserleri ve İslam Düşüncesine Katkısı [Ahmad Mahmoud Subhi's Life, Works and Contribution to Islamic Thought]”. Marifetname. 8/2

(Aralik/2021), s. 757-786.

\section{İntihal | Plagiarism}

Bu makale, iThenticate aracılığıyla taranmış ve intihal tespit edilmemiştir.

This article, has been scanned by iThenticate and no plagiarism has been detected.

\section{Copyright $($ C}

Published by Siirt University Faculty of Divinity. Siirt/Turkey. web: https://dergipark.org.tr/tr/pub/marifetname mail: sifdergisi@gmail.com 


\section{Ahmed Mahmûd Subhî'nin Hayatı, Eserleri ve İslam Düşüncesine Katkısı}

Öz: Tarihsel süreç içerisinde disiplinlerarası çalışma yapmanın önemi sosyal bilimlerin tamamında kabul görmüş ve artık yadsınamayacak bir olgu haline gelmiştir. İslam düşünce tarihi de kuşkusuz böyle bir çalışma için çok verimli bir alan olarak görülebilir. Zira birçok farklı disiplin tarihsel oluşum sürecini aynı noktadan başlatır, tarihsel olarak ortak bir anlatı üzerine kurgulanır. Disiplinlerarası okuma bu açıdan en çok İslam düşüncesinin sacayakları olarak ifade edebileceğimiz usûl-1 fikıh, kelâm, felsefe ve tasavvuf bağlamında işlevsel olabilir. Bu çerçevede, çalışmamızda Mısırlı düşünür ve akademisyen Ahmed Mahmûd Subhîyi prototip olarak belirledik. Nitekim Subhî bütüncül bir İslam düşüncesi algısıyla ön plana çıkan bir yaklaşıma sahiptir ve söz konusu fikri inşa edebilecek metinler üretmiştir. Subhî’nin düşünme tarzını bağlı bulunduğu bir gelenekle veya hoca-talebe ilişkisi içerisinde inşa edebiliriz. Bunun için yapılması gereken hayatı ve eserlerine derinlemesine bir bakış atmaktır. Bu tür bir inceleme Subhînin ilmî metodunu anlamamızda anahtar işlevi görecektir. Bu çalışmanın nihai gayesi İslam düşüncesine dair sağlıklı ve doğru yorumlar yapabilmek için farklı disiplinleri temele almanın önemini vurgulamaktır. Bir iddia olarak dile getirdiğimiz bu husus, Subhînnin metinlerindeki fikirleriyle tecessüm ettirilecek ve somut bir yapıya dönüştürülecektir.

Anahtar Kelimeler: İslam Felsefesi, Ahmed Mahmûd Subhî, Disiplinlerarasılık, İslam Düşüncesi, Kavram Analizi, Tümevarım, Tümdengelim, İndirgemecilik.

\section{Ahmad Mahmoud Subhi's Life, Works and Contribution to Islamic Thought}

Abstract: In the historical process, the importance of doing interdisciplinary work has been accepted in all social sciences and has become an undeniable phenomenon. The history of Islamic thought can undoubtedly be seen as a very fertile field for such a study. It is because many different disciplines start the historical formation process from the same point. In other words, they are historically constructed on a common narrative. In this respect, interdisciplinary reading can be most functional in the context of usûl-1 fiqh, kalam, philosophy and mysticism, which can be expressed as the pillars of Islamic thought. In this framework, we have identified Ahmed Mahmûd Subhi, the Egyptian thinker and academician, as a prototype in our study. As a matter of fact, Subhi has an approach that stands out with a holistic perception of Islamic thought and has produced texts that can build the idea in question. We can build Subhî's way of thinking with a tradition he abides by or in a teacher-student relationship. What is needed for this 
is to take an in-depth look at his life and works. Such a study will serve as the key to our understanding of Subhi's scientific method. The ultimate aim of this study is to emphasize the importance of taking different disciplines as a basis in order to make healthy and correct interpretations of Islamic thought. This issue, which we have expressed as a claim, will be embodied by Subhîs ideas in his texts and turned into a concrete structure.

Keywords: Islamic Philosophy, Ahmad Mahmoud Subhi, Interdisciplinarity, Islamic Thought, Concept Analysis, Inductive Method, Deductive Method, Reductionism.

\section{Giriş}

İslam düşüncesi üzerine yapılan birçok çalışma ve bir o kadar araştırmac1 düşünüldüğünde Ahmed Mahmûd Subhî [ö. 2004] gibi Türk akademyasında çok fazla tanınmayan birisini çalı̧̧ma konusu yapmanın gerekçesi haklı olarak sorulabilir. İslam düşüncesine bütüncül ve disiplinlerarası bir okumayla yaklaştığı için Subhî, incelememizin konusu olmuştur.

Subhî̀nin hayatı, eserleri ve İslam düşüncesine katkısını inceleyeceğimiz bu araştırmada yeni ufuk ve bakış açılarının neşet etmesine ön ayak olmayı umut ediyoruz. Her bir disiplinin müstakil olarak bağımsızlığını ilan etmesi birçok alanın kendisini daha öncelikli ilim olarak görmesine sebep olmuştur. Nitekim İslam düşünce geleneğindeki eşref-i 'ulûm tartı̧maları bunun en bariz tezahürlerindendir. Dolayısıyla bu kısır döngüyü sonland1ran bir nazar ile İslam düşüncesinin meselelerine bakan Subhî önemli bir düşünür olarak karşımıza çıkar.

Subhî’nin ilmî üslûbunda önce çıkan birçok husus vardır. Bunlardan biri, İslam düşüncesinin belirli disiplinler özelinde okunması ve yorumlanmasına karşı olan tavrıyla indirgemeci tutumlara karşı olan tavrıdır. İkincisi kavramların izini farklı sahalardan hareketle sürmesi ve kavram analizini metodunu kullanmasıdır. Subhî̀yi değerli kılan bir diğer nokta eserleri dikkatle tetkik edildiğinde ortaya çıkan iki kavramda kendini gösterir: Tümevarım ve Tümdengelim. Bu iki metodu kullanarak İslam düşüncesine dair doğru bir okuma gerçekleştirmenin mümkün olduğunu göstermeye yönelik gayretinden ötürü Subhî nazarı dikkatimizi celbetmiştir. Aslında İslam düşüncesinin mebdeleri olarak görülmesi elzem olan sahaları, sanki biri 
diğerinin mukâbili imiş gibi değerlendiren yaklaşımlar Subhî̉nin zaman zaman doğrudan zaman zaman da zımnen eleştirilerine maruz kalır. İşte Subhî tarafından dile getirilen bu tenkitler daha çok tümdengelim metodu ile tecessüm eder.

Bu çalı̧̧mada Subhînin ilmî üslûbu, farklı eserlerinden ve problem sahalarından örnekler verilerek incelenecektir. Ancak Türk akademyasında çok tanınmaması hasebiyle evvelâ Subhînin hayatı ve eserlerine değinilecektir.

\section{Hayatı}

İslam düşüncesi üzerinde Zekî Necip Mahmûd, Ali Sâmî en-Neşşâr, Abdurrahman Bedevî, İbrahim Medkûr, Mahmûd Kâsım gibi önemli isimler hatırı sayılır düzeyde yayın yapmışlar ve bu saha üzerinde çalışma yapan neredeyse herkes için birer başvuru merci haline gelmişlerdir. Ahmed Mahmûd Subhî onlar kadar bilinmese de ortaya koyduğu muhtelif eserlerle en az onlar kadar hatırlanmayı hak etmektedir.

Ahmed Mahmûd Subhî 1928 yılında İskenderiye şehrinde dünyaya gelmiş, 2004 y1lında vefat etmiştir. İskenderiye'deki Abbasi Ortaokulunda öğretmenlik, felsefe alanında yüksek lisans, İskenderiye Üniversitesi Edebiyat Fakültesi felsefe bölümünde İslam felsefesi profesörü ve bölüm başkanı olarak görev yapmıştır. 1976 yılında Üniversite'nin teşvik ödülüne layık görülmüştür. Daha sonra vefat ettiği 2004 senesine kadar Libya, Yemen ve Kuveyt gibi Arap dünyasındaki birçok ülkede farklı üniversitelerde çalışmıştır. Ali Sâmî en-Neşşâr'ın öğrencilerinden olan Subhînin, hocası ile birlikte İslam düşünce mirasının temsilcilerinden olduğu sünnî ve Şî̂ otoriteler tarafindan kabul edilir. ${ }^{1}$

Subhî; kelâm, felsefe ve mezhepler tarihi alanlarında ihtisas yapmıştır. Disiplinlerarası çalışma yapmanın önemini, neşrettiği eserlerinde göstermiştir. Subhî, Türkiye'de daha çok $\mathrm{Mu}^{\prime}$ tezile$^{2}$, Eş'arîye ${ }^{3}$ ve Zeydiy-

1 Züheyr Gazzâvî, “et-Tiyâru'l-istirdâdî'l-felsefiyyi'l-mırriyyi ve dirâsetü’şs şi 'ati'l- imâmiyye isnâ 'aşeriyye”, Mecelletü'l-minhâc 2 (1996), 77.

2 İlyas Çelebi, "Mu'tezile", TDV İslam Ansiklopedisi (İstanbul: Türkiye Diyanet Vakfı Yayınları, 2006).

3 İrfan Abdülhamîd Fettâh, “Ebü'l-Hasan Eş’arı̂”(İstanbul: Türkiye Diyanet Vakfi Yayınları, 1995). 
$\mathrm{ye}^{4}$ üzerine yazdıklarıyla bilinir ve bu eserlerine atıf yapılır. Subhî'nin bu konular dışında ayrıca felsefe, kelâm ve tasavvuf üzerinden ahlâkı ele aldığ1 el-Felsefetül-ahlâkiyye fi fikri'l-İslâm el- 'akliyyûn ve'z-zevkiyyûn evi'n-nazar ve'l- amel isimli doktora tezi de ahlâk felsefesi çalı̧̧anların dikkatini çekmiştir. ${ }^{5} \mathrm{Bu}$ tezin giriş kısmı ilk olarak 1997 yılında Erzurum'da yerel bir dergide yayınlamıştır. ${ }^{6} \mathrm{Bu}$ çalışmanın akabinde Subhîye ilk yer veren ismin Harun Anay olduğunu söyleyebiliriz. Anay İslam düşüncesi üzerine hazırlamış olduğu büyük emek mahsülü olan bibliyografya çalışmalarında Subhî’ye ve bazı eserlerine yer vermiştir. ${ }^{7}$

Meyhûb'un ifadesiyle Subhî denilince kadîm geleneğin en önemli temsilcilerinden biri akla gelir. Aynı zamanda Subhî asrın diliyle gelenek içerisinde yaşayan problemleri çözebilmek için kelâm ilmine yenilikçi fikirlerle yaklaşmıştır. ${ }^{8}$

Subhî yukarıda işaret edilen eserlerinin yanı sıra oldukça münbit bir düşünürdür. Aşağıda künyeleri verilen eserlerin sadece isimleri bile Subhînnin çok yönlülüğüne işaret eder.

\section{Eserleri ${ }^{9}$}

\subsection{Kitap}

Subhî’nin münevver portresinin en net görüleceği yer, şüphesiz kitaplarıdır. Ancak kaleme aldığı eserlerindeki kronolojik sıra Subhî hakkındaki değerlendirmelerimizi daha doğru kılacak bir bakış açısı verme im-

4 Yusuf Gökalp, “Zeydiyye”, TDV İslam Ansiklopedisi (İstanbul: Türkiye Diyanet Vakfi Yayınları, 2013).

5 Hümeyra Özturan, "İslâm Ahlâk Çalışmalarının Dünü ve Bugününe Dair Bir İnceleme", $\dot{I}_{s}$ lam Ablak Literatürü Ekoller ve Problemler, ed. Ömer Türker, Kübra Bilgin (İstanbul: Nobel Yayın Dağıtım, 2016), 14.

6 Ahmed Mahmûd Subhî, "İslam Düşüncesinde Ahlâk Felsefesi”, çev. Nadim Macit, Düşünce ve Kültür Dergisi 1 (1997), 55-69.

7 Harun Anay, “Çağdaş Arap Düşüncesi Üzerine”, Divan: Disiplinlerarası Çalışmalar Dergisi 10 (2001), 70; Harun Anay, “İslam Düşüncesi ve Batı Felsefesiyle İlgili Arapça Yüksek Lisans ve Doktora Tezleri”, Divan: Disiplinlerarası Calışmalar Dergisi 10 (2001), 294.

8 Seyyid Abdüssettâr Meyhûb, Haulâi'l-müsakkafûn ve fikrubumu'l-islâhî (Santa Anita: Mektebetü's-sikâfeti'd-dîniyye, 2018), 48-49.

9 Subhînnin matbu ve elektronik olarak ulaşabildiğimiz tüm eserlerinin muhtevaları hakkında genişçe bilgi vermeye çalıştık. Ulaşamadığımız metinlerin sadece künye bilgilerini vermekle yetindik. 
kanını taşımamaktadır. Zira eserlerinin taalluk ettiği sahalar muhteliftir. Şayet aynı konu üzerinde yazdığı metinler olsaydı, zaman içerisinde nasıl bir yorum farklılığına gittiğini görebilirdik. Dolayısıyla çalışma boyunca kronolojik bir sıralamayı takip etmeksizin künye-muhteva bilgileri paylaşılacaktır.

Üçleme şeklinde kaleme alınan aşağıdaki ilk üç eser, Subhî̀nin farklı eğilimlere sahip Müslüman firkaları bütüncül bir sistem içerisinde ele alma çabasının ürünüdür:

\section{Fi 'ilmi kelâm: Mu'tezile 10}

Subhî bu eserine kelâm ilminin tarifi, konuları, isimlendirilmesi ve doğuşunda etkili olan faktörler ile başlar. Akabinde beş ilkeyi ve Mu'tezilî düşüncenin doğduğu, olgunlaştığı ve en önemli temsilcileri ile son dönemini izah eder. Nihayet Mu'tezile düşüncesinin rolü başlığında genel değerlendirmeler ile eseri hitama erdirir. Eserin başında okuyucuya Müslüman firkalar karşısında kazandırmak istediği bakış açısını maddeler halinde zikretmektedir. Subhînnin zikrettiği bu hususlar özelde bu eser hakkında bilgi verirken genelde ise O'nun İslam düşüncesinde takip ettiği metotlara dair birçok şey söylemektedir. Bu noktaya, 'Subhînnin İslam Düşüncesine Katkısı' başlığı altında ayrıntılı bir şekilde değineceğiz.

Fi 'ilmi kelâm: Eş'ariyye11

Eser, İslam düşüncesi ve Eşarâilik başlıklı bir giriş yazısıyla başlar. Burada hicri dördüncü asırda İslam medeniyetinin özellikleri, kelâm ilminin gelişimi ve Eş'arîliğin rolü, önde gelen Eş'arî düşünürler ve Eş'arîliğin doğuşunda etkili olan amiller anlatılarak genel bir çerçeve çizilir. Eş'arî düşünürler bu ekolün doğuşu ve şekillenişinde, kâmil bir inanç sistemine dönüşünde, felsefî kelâm ilminin oluşumunda rol alanlar şeklindeki bir sistem içerisinde anlatılır. Bu tarz bir kurgu hangi düşünürün Eş'arîliğge nasıl katkı yaptığını göstermesi açısından oldukça değerlidir. Subhî İslam düşüncesinin gerilemesinde Eş'arîliğin rolü başlı̆̆ıyla eserini sonlandırır.

10 Ahmed Mahmûd Subhî, $F i$ 'ilmi kelâm dirâsetün felsefiyyetün li ârâi'l-firakil-İslâmiyyeti fi usûlid-dîn: Mu 'tezile (Beyrut: Dâru'n-nahdati'l- 'arabiyye, 1985).

11 Ahmed Mahmûd Subhî, $F i$ 'ilmi kelâm dirâsetün felsefiyyetün li ârâi'l-firaki'l-İslâmiyyeti fi usûli'd-dîn: Eş 'ariyye (Beyrut: Dâru'n-nahdati'l- 'arabiyye, 1985). 


\section{Fi 'ilmi kelâm: Zeydiyye 12}

Birden fazla baskısı yapılan bu eser ayrıntılı bir şekilde Şîa'nın bir fırkası olan Zeydiyye mezhebini anlatır. İlk bölümde, Şiî düşüncenin doğuşu ve Şiî firkalar izah edilmekte ve 'neden diğer sahabenin değil de Hz. Ali'nin taraftarları olmuştur?' sorusu cevaplandırılır. İkinci bölüm İmam Zeyd, Zeydiyye firkaları ve İmam Zeyd'e tabi olanlar, istişhad ve cihad imamları gibi konuları kapsar. Üçüncü bölüm yönetime karşı çıkma savunucuları (hurûc 'ale's-sultân) ve devlet kuranları konu edinir. Kitapta daha sonra gelen bölümlerde sırasıyla Zeydîliğin Mu'tezili taraftarları, Zeydîliğin Mu'tezili muarızları, Ehl-i Sünnet'e karşı açık fikirli Zeydî eğilimler konuları işlenir. Eserin sonuç kısmında lehinde ve aleyhinde ifade edilenlerle birlikte Zeydiyye mezhebi ele alınır. Subhî modern dönemde Zeydiyye'nin yaşadığı fikrî krizlerden ve Zeydî imamlar silsilesinden bahsederek kitabını bitirir.

Fikretül-imâme 'indeş-ş̂े'a el-isnâ 'aşeriyye 13

İskenderiye Üniversitesi Edebiyat Fakültesi'nde 1962 yılında Ali Sâmî enNeşşâr'ın danışmanlığında hazırladığı yüksek lisans tezidir. 499 sayfadır. ${ }^{14}$ Subhî̀nin bu tezi benzer bir isimle Nazariyyetüll-imâmiyye ledâ eş-şî́ ati'lisnâ 'aşeriyye tahlîlün felsefiyyetün li'l- 'akîde başlığı altında daha sonra bir yayınevi tarafından basılmıştır. ${ }^{15}$ Subhî bu metinde Şî̂ düşüncenin en temel kavramı sayılan imâmiyye teorisini ve aynı zamanda inanç esasını felsefî bir analizle inceler. İlk bölümde Şîa ve İmâmiye teorisi, Müslümanlara göre dinî siyaset, Ehl-i sünnet ve Şî́da imâmet kavramı etrafinda ele alan Subhî, peygamberin siyasi şahsiyeti başlığıyla ilk bölümü sonlandırır. İkinci bölüm, on iki imam Şî̀sında imâmet mefhumu, imâmetin Allah tarafından vacip oluşu, imamın masum olması gerektiği, imamın ilmi, en faziletli olanın imam olması gerektiği, imamın marifetinin gerekli olması gibi konuları içerir. Üçüncü bölüm Hz. Ali etrafında oldukça kritik bazı

12 Ahmed Mahmûd Subhî, $F i$ 'ilmi kelâm dirâsetün felsefiyyetün li ârâi'l-firaki'l-İslâmiyyeti fi usûlid-dîn: Zeydiyye (Beyrut: Dâru'n-nahdati'l-' arabiyye, 1991).

13 Ahmed Mahmûd Subhî, Fikretü'l-imâme 'inde'ş-şî̀ a el-isnâ 'aşseriyye (Kâhire: İskenderiye Üniversitesi, Yüksek Lisans Tezi, 1962).

14 Anay, “İslam Düşüncesi ve Batı Felsefesiyle İlgili Arapça Yüksek Lisans ve Doktora Tezleri”, 294.

15 Ahmed Mahmûd Subhî, Nazariyyetül-imâmiyye ledâ eş-şî̀'ati'l-isnâ 'aşeriyye tablîlün felsefiyyetün li'l- 'akîde (Beyrut: Dârü'n-nahdati'l- 'arabiyye, 1991). 
sorulara hasredilmiştir: 'Kur'an Ali'nin imametine işaret eder mi? Peygamber Ali'ye vasiyet etmiş midir?' Bunların yanı sıra eser, Ali’nin kişiliği ve Şîa'nın inanç kuralları ile Ali'nin ilkeleri arasında mukayeseyi konu edinir. Dördüncü bölümde on iki imamlar silsilesi anlatılır. Son bölümde Subhî imamet fikrini İslami birçok firka ve saha içerisinde mukayeseli bir şekilde ele alarak kitabını hitama erdirir.

el-Felsefetü'l-ablâkiyye fi fikri'l-İslâm el- 'akliyyûn ve'z-zevkiyyûn evi'n-nazar ve'l- 'amel16

Subhînnin Ali Sâmî en-Neşşâr'ın danışmanlığında tamamladığı doktora tezidir. Birçok baskısı yapılan eser ahlâk felsefesi bağlamında kalem oynatan müelliflerin kayıtsız kalamadığı önemli bir eserdir. Eseri mühim kılan birçok noktanın var olduğunu söylemek gerekir. Meryem Attâr'ın ifadesiyle eser İslam'da felsefî ahlâk düşüncesini doğru bir şekilde ele alan en kapsam11 metindir. ${ }^{17}$ Subhî bu eserinde klasik ahlâk felsefesi anlatımının ötesine geçer. İslam düşüncesinin temel dinamikleri dediğimiz kelâm, felsefe ve tasavvuf üzerinden farklı bir ahlâk felsefesi okuması yapar. Bu okuma disiplinlerarası çalışmayı 1970'li yıllarda yapmıs olması sebebiyle mühimdir. Eserin kaynaklarına girildiğinde İslam düşüncesinin klasiklerinin yanı sıra psikoloji ve psikanaliz gibi modern disiplinlerin klasiklerine de başvurulduğu görülür. Ayrıca Aristocu anlamda bir ahlâk felsefesinden ziyade klasik kelâm ve tasavvuf kitaplarındaki meseleleri detaylı bir şekilde inceleyerek alternatif bir ahlâk felsefesi inşa etme çabası dikkate değerdir.

et-Tasavouf îcâbiyyatuhu ve selbiyyâtubu ${ }^{18}$

Müspet ve menfi yönleriyle tasavvuf isimli bu kitap Subhînin daha önce

16 Ahmed Mahmûd Subhî, el-Felsefetül-ablâkiyyefifikri'l-İslâm el-'akliyyûn ve'z-zevkiyyûn evi'nnazar ve'l-'amel (Kâhire: Dâru'l Ma'ârif, 1983). İlgili eser bu çalışma hakem değerlendirme sürecinde iken Türkçe'ye tercüme edilmiştir. Bk. Ahmet Mahmut Suphi, İslâm Düşüncesinde Ablâk Felsefesi, ed. Muammer İskenderoğlu, çev. Abdurrahman Harbi vd. (İstanbul: Litera Yayıncilik, 2021).

17 Mariam al-Attar, Islamic Ethics: Divine Command Theory in Arabo-Islamic Thought (New York ; London: Routledge, 2010), xix. Krş. Meryem Attar, İslam Ablakı İslam Düşüncesinde İlâhî Emir Teorisi, ed. Muammer İskenderoğlu, çev. Enver Şahin vd. (İstanbul: Litera Yayıncılık, 2019), 25.

18 Ahmed Mahmûd Subhî, et-Tasavvuf îcâbiyyatuhu ve selbiyyâtuhu (Kâhire: Dâru'l Ma'ârif, 1984). 
aynı isimle yayımlamış olduğu bir makalenin genişletilmiş şeklidir. ${ }^{19}$ Eser giriş, üç bölüm ve sonuç şeklinde kurgulanmıştır. İlk bölümde İslam'da tasavvufun ortaya çıkışı hakkındaki karışıklıklar, ikinci bölümde kelamcıların tasavvufa karşı olan tepkileri ele alınır. Son bölüm ise tasavvufu genel olarak diğer insani düşüncenin tezahürlerinden, özel olarak da İslami tezahürlerden ayıran şeylerin ne olduğu hakkındadır.

\section{İmâmu'l-müctehid Yahya b. Hamza ve ârâuhu'l-kelâmiyye 20}

Subhî, Zeydîlik ve Yemenîlik arasında bir şahsiyet olarak tanımladığı yaşadığı dönemi, hayatını ve eserlerini eserin giriş kısmında verir. Yahya b. Hamza’nın, kelâmî görüşlerini olumlu, eleştirel ve amelî olmak üzere üç açıdan ele alır. Olumlu yön başlığı altında, ilahiyyat, nübüvvet, imamet, Esma-ahkâm ve uhrevi konuları; eleştirel yönde kafir sayılan firkalara ve diğer dinlere dair görüşleri; amelî yönde ise emr-i bi'l-ma'ruf nehy-i 'ani'lmünker ve ahlâk konuları incelenir.

\section{Fi Felsefeti't-târîh 21}

Subhî bu eserini iki bölüm şeklinde kurgulamıştır. İlk bölümde öncelikle tarihe dair idealist, pozitivist, tarihsel ve natüralist yaklaşımlardan bahseder. İdealist ve pozitivist yaklaşımları savunanların delillerini öne sürer, iki yaklaşım arasında mukayese yapar ve orta bir yolun varlığına işaret eder. $\mathrm{O}$ idealist ve pozitivist yaklaşımın felsefî arka planına dair genel bir çerçeve çizmektedir. 'Tarih dediğimiz olguyu meydana getiren şahıslar mı yoksa medeniyetler midir?' sorusunu müstakil bölümler halinde inceler. Tarih hakkında yapılan değerlendirmelerin objektif veya ahlâkî olup olmadıklarını bahis mevzusu eder. Tarihsel yaklaşım da dahil olmak üzere eserdeki tüm konular temsilcileriyle izah edilir. Eserin ikinci bölümünde tarih felsefesi hakkındaki anlatılara yer verilir. Medeniyetlerin rolü üzerinden tarih felsefesi yapan İbn Haldûn ve Giambattista Vico'nun görüşleri zikredilir. İlahi inayet ve insanın fiilleri konularını tarih felsefesi bağlamında öne çıkan temsilcileriyle tartı̧ır. Tarih felsefesinin boyutları Hegel'de metafizik

19 Ahmed Mahmûd Subhî, “et-Tasavvuf îcâbiyyatuhu ve selbiyyâtuhu”, Mecelletü 'âlemi'l-fikr 6/2 (1975), 15-60.

20 Ahmed Mahmûd Subhî, İmâmu'l-müctehid Yahya b. Hamza ve ârâuhu'l-kelâmiyye (Kâhire: Dârün-nahdati'l-'arabiyye, 1990).

21 Ahmed Mahmûd Subhî, Fi Felsefeti't-târîh (Kâhire: Müessesetü’s-sikâfeti'l-câmi'iyye, 1975). 
yön, Marks ve Engels'de iktisadî yön, Spengler'de biyolojik yön, Toynbee'de dinî medeniyetler yönü şeklindeki başlıklar etrafında incelenir. Subhî bu eseriyle ilgili daha sonra akademik bir dergide yayınlanan bir röportaj da vermiştir. 22

Fi Felsefeti't-tıp 23

Subhî, Mahmûd Fehmî Zeydân ile ortak kaleme aldıkları tıp felsefesi isimli bu eserde adeta felsefenin gücünü göstermeye çalışır. 1993 yılında yayımlanan bu eser üç bölüm ve bazı klasik eserlerin yer aldığı ekler bölümünden ibarettir. İlk bölümde, felsefî bir bakış açısıyla antik ve modern tıp arasında bir değerlendirme yapılır. Burada kadîm tıbbın aslında felsefî bir sistem içerisinde olduğu ve modern deneysel tıbbın felsefî bir ekolü takip ettiği iddia edilir. İkinci bölüm, Yunan ve İslam tıbbının çeşitli açılardan mukayese edildiği bir bölümdür. Tıp felsefesi tıbbî ahlâk isimli üçüncü bölümde, tıp ve sağlık felsefesi, sağlık ve hastalığın anlamları, tıp ilminin nasıl ilerleyebileceği konuları müzakere edilir. Hastalığın tıbbi olarak teşhisi hakkında vaz edilen teoriler işlenir.

\section{Ve Hameleha'l-insân: Makâlâtün Felsefiyyetün ${ }^{24}$}

Subhî̀nin, makalelerini derlediği kitap iki bölümden oluşmaktadır. İlk bölümde İslam felsefesi, ikinci bölümde ise genel felsefeye dair bahisler vardır. Makaleler başlığı altında bu eserin muhtevasını oluşturan metinlerin ayrınt1lı künyeleri verilecektir.

el-Babreyn ve'd-da'va $\hat{I} r a ̂ n ~ 25$

Subhî̀nin İskenderiye’de Abbasi Lisesinde öğretmenlik yaptı̆̆ı dönemde yazdığı bu metin telif olarak ürettiği ilk metindir. Bağdat Üniversitesinde çağdaş Arap Tarihi hocası Mahmûd Ali Dâud esere takdim yazmıştır.

\section{Cüzûru'l-irhâb fil-akîdeti'l-vahbâbiyye26}

Vahhâbi inancında terörün kökenleri isimli eser muhtemelen Subhînnin ya-

22 Yahya Hamûd - Ahmed Mahmûd Subhî, "Fi Felsefeti't-târîh", El-Fikru'l-'arabî 4/28 (1982), 222-233.

23 Ahmed Mahmûd Subhî - Mahmûd Fehmî Zeydân, Fi Felsefeti’t-tıb (Beyrut: Dârün-nahdati'1'arabiyye, 1993).

24 Ahmed Mahmûd Subhî, Ve Hameleha'l-insân: Makâlâtün Felsefiyyetün (Beyrut: Dârü'nnahdati'l-'arabiyye, 1997).

25 Ahmed Mahmûd Subhî, el-Bahreyn ve'd-da'va Îrân (İskenderiyye, 1963).

26 Ahmed Mahmûd Subhî, Cüzûru'l-irhâb fi'l-akîdeti'l-vahhâbiyye (b.y.: Dâr'un-nasr, 2008). 
rım kalmış bir eseridir. Zira eserin basım yılı 2008 gözükmektedir. Ahmed Subhî Mansûr'un giriş yazdığ 1 ve eserin sonunda yine Mansûrla yapılan bir röportajın metne dâhil edilmesi de bu konudaki kanaatimizi haklı çıkarır niteliktedir. Eser Vahhâbiliğin dünü, bugünü ve yarını hakkında bilgiler verip Misır ve Vahhâbilik arasındaki ilişkiyi inceler.

\section{Hâumu ikraû kitâbiyeb: Muhâveletün li teceddüdi'l-fikri'l-İslâmiyyi 27}

1996 yılında neşr edilen eser, Subhî̀nin İslam düşüncesine yönelik ıslah çabalarını genel hatlarıyla ortaya koyduğu eseridir.

Neşetül-fikri'l-felsefiyyi 'inde yunan 28

Hocası Ali Sâmî en-Neşşar ile Subhînnin ortak olarak kaleme aldıkları eser Yunanda felsefe fikrinin doğuşunu inceler. ${ }^{29}$

Fi Felsefeti'l-hadârat: el-Yûnâniyye, el-İslâmiyye, el-Ğarbiyye30

Subhînnin talebesi Safâ Abdusselâm Ca'fer ile birlikte kaleme aldıkları medeniyet tarihi Yunan, İslam ve Batı üçgeninde yazılmıştır.

Beyne't-te'rîh ve't-tahdîs 31

Bu metin Subhî̀nin Fi Felsefeti't-târîh isimli eserinin sonuna ilave ettiği aynı başlıklı bir makalenin genişletilmiş ve kitaba dönüştürülmüş şeklidir. Subhî, tarih ve hadis ilimlerini metotlarını mukayese ederek bir inceleme yapar. Bu okuma biçimine akla gelebilecek soruları tahmin eden müellif, geçmişte yaşanmış olayları inceleyen tarih ilmiyle Hz. Peygamberin söz, fiil ve takrirlerini inceleyen hadis ilminin birbirinden farklı olduğunun farkındadır. Zira hadis İslam'a özgü şeylerle irtibat kurarken tarih ise her türlü mekan ve zamanda olagelen şeylerle irtibat kurar. Ancak Subhî konuları açısından değil yöntem açısından bu mukayeseyi yapmaktadır.

Makâlâtün mubtâratün fi'l-felsefeti'l-İslamiyyi32

27 Ahmed Mahmûd Subhî, Hâumu ikraû kitâbiyeb: Muhâveletün li teceddüdi'l-fikri'l-İslâmiyyi (Beyrut: Dârün-nahdati'l-'arabiyye, 1996).

28 Ali Sâmî Neşşâr - Ahmed Mahmûd Subhî, Neş'etüll-fikri'l-felsefiyyi 'inde Yunan (Beyrut: Dârü'n-nahdati'l-' arabiyye, 1996).

29 Saîd Murâd, "Ali Sâmî Neşşâr”, TDV İslam Ansiklopedisi (İstanbul: Türkiye Diyanet Vakfi Yayınlar1, 2007), 33/22.

30 Ahmed Mahmûd Subhî - Safâ Abdusselam Ca fer, Fi Felsefeti'l-hadârat: el-Yûnâniyye, elİslâmiyye, el-Ğarbiyye (Beyrut: Dârü'n-nahdati'1-'arabiyye, 1999).

31 Ahmed Mahmûd Subhî, Beyne't-te'rîh ve't-tahdîs (İskenderiyye: Müessesetü's-sikâfeti'lcâmi 'iyye, 1975).

32 Ahmed Mahmûd Subhî, Makâlâtün mubtâratün fi'l-felsefeti'l-İslamiyyi (İskenderiyye: Dârü'1- 
Subhînnin bu metni, İslam felsefesi sahasında muayyen problem ve filozoflar hakkında derlemiş olduğu seçme makalelerinden müteşekkil bir diğer eseridir.

\section{Hel Yu 'iddu el-mezhebu'l-vahbâbiyye selefiyyen 33}

70 sayfalık kısa bir metin olan bu eserde Subhî, Muaviye döneminde yaşanan hadiselerden başlayan bir giriş ve üç bölüm şeklinde eserini kurgulamıştır. İlk bölümde tefsir alanında İbn Abbas'tan fikıh alanında Ahmed b. Hanbel'den başlayarak selef-i salih hakkında bilgi verir ve gerçek selefîlerin özelliklerini zikreder. İbn Abbas'in tefsirinden örnekler verir. Düşünür ikinci bölümde İbn Teymiyye ve İbn Abdulvehhâb'ın iddiaları ile metotlarını zikreder. Son bölümde ise mescid-i haram alimlerinin verdikleri fetvaları siralar.

Yukarıda detaylı bir şekilde ortaya konulan eserleri dışında danışmanlığını yaptığı bazı çalışmalara da yer vermenin Subhîyi ve onun düşünme tarzını ortaya koyma açısından önemli buluyoruz.

\subsection{Kitap Bölümü}

İtticahâtül-felsefeti'l-İslâmiyye fil-vatani'l- 'arabi 34

Yukarıda kısmî bir atıf yaptığımız Subhî’nin bu metni, bir kitap bölümü olarak kaleme alınmıştır. Metin, 'Çağdaş Arap Dünyasında Felsefe' isimli kitabın bir bölümü olarak 1987 senesinde Beyrut'ta yayımlanmıştır. Subhî Arap dünyasında felsefenin serencamını anlattığı bu metninde dört aşamalı bir kurgu yapmıştır: İlk aşama I. Dünya Savaşının sonuna kadar XIX. yüzyıl boyunca İslam dünyası üzerindeki Avrupa hâkimiyetinin gelgitlerinin anlatıldığı dönemdir. İkinci aşama I ve II. Dünya Savaşları arasındaki dönem, üçüncü aşama ise 1945-1960 arası dönemdir. Dördüncü aşama 1960-1980 arası dönemdir. Bu kurgunun nihai hedefini metnin içerisindeki şu satırlar en iyi şekilde ifade eder:

Vefâ, 2001).

33 Ahmed Mahmûd Subhî, Hel Yu iddu el-mezhebu’l-vahhâbiyye selefiyyen (İskenderiyye: y.y., 2004).

34 Ahmed Mahmûd Subhî, “İtticahâtü'l-felsefeti'l-İslâmiyye fi'l-vatani'l- arabi (1960-1980)”, el-Felsefetü fi'l-vatani'l- 'arabiyyi'l-mu 'âsır, ed. Ahmed Mâzî (Beyrut: Merkezu Dirâsâti'lvahdeti'l-'arabi, 1987), 101-119. 
"Müslüman ve Arapların ilimlerindeki her bir fikrin yabancı kaynaklı oluşuna bağlayan araştırmalardaki bu kabulün ortadan kalktığını açıklamak ve İslam felsefesi düşüncesindeki araştırmacıların bakışlarını aslî meselelere yönlendirmektir.”

Dirâsetün nakdiyyetün li ba 'di'l-müşkilâti'l-kelâmiyye min manzûri luğaviyyi mantıkiyyin 35

Bu metin, İbn Rüşd üzerine yazdıklarıyla tanınan düşünür ve akademisyen Mahmûd Kâsım'a ithaf edilen bir anma kitabında yer almaktadır. Metnin temel gayesi, İslam düşünce tarihinde kelâm sahasının en temel problemleri denilebilecek haberî sıfatlar, zât-sıfât ilişkisi, kesb teorisi ve insanın fiilleri konularını farklı bir dille ele almaktır. Başlıktan da anlaşıld1ğ1 üzere metinde mantıkî form şeklinde temayüz eden bu dil, bazı kelâm problemlerine dair eleştirel bir inceleme yapar. ${ }^{36}$

\section{Zeki Necîb ve İskâliyyetü'l-asâlet ve'l-mu' âsara 37}

Üstadımız dediği Zeki Necîb Mahmûd'un vefatının akabinde kaleme aldığı bu metne Zeki Necîb'in iki yönüne işaret ederek başlar: Felsefeyi, aleyhinde birçok olumsuz şeyle anılmaktan kurtarması ve üniversite tedrisine başladığ 1 dönemden bu yana fikrî faaliyetleri etkilemesidir. Metnin devamında Zeki Necîb’i özgün ve çağdaş kılan noktalar anlatılır.

\section{'Âbdurrabman Bedevî: Feylesûfu'l-mütervahbid38}

Subhî, Abdurrahman Bedevînin anısına kaleme alınan bu metne, Bedevî̀nin mütevahhid bir filozof olduğu iddiasıyla katkı sunmuştur. Metnin ilk satırları Misır milliyetçiliği yapan iktibas ve ifadelerle doludur. Mustafa Kâmil'in 'Mısırlı olmasaydım, Mısırlı olmayı isterdim' sözü buna örnek olarak zikredilebilir. Düşünürümüz dâhî mütefekkirlerin Arap dev-

35 Ahmed Mahmûd Subhî, "Dirâsetün nakdiyyetün liba 'di'l-müşkilâti'l-kelâmiyye min manzûrin luğaviyyin mantıkiyyin”, Mahmûd Kâsım el-İnsân ve'l-feylesûf 1913-1973 Kitâbu'n tizkârî, ed. Hâmid Tâhir (Kâhire: Mektebetü'l-Angolo el-misriyye, 1995), 373-394.

36 Subhî, "Dirâsetün nakdiyyetün li ba 'di'l-müşkilâti'l-kelâmiyye min manzûrin luğaviyyin mantıkiyyin”, 373.

37 Ahmed Mahmûd Subhî, “Zeki Necîb ve İşkâliyyetü'l-asâle ve'l-mu âsara”, Zeki Necip Mahmûd Müfekkiren 'Arabiyyen ve râiden li't-ticâbi'l- 'ilmi't-tenvîr, ed. 'Âtıf el-'Irâkî (İskenderiyye: Dârü'l-Vefâ, 2001), 151-162.

38 Ahmed Mahmûd Subhî, “'Âbdurrahman Bedevî: Feylesûfu'l-mütevahhid”, 'Âbdurrabman Bedevî Dirâsâtün Mehdâtün, ed. Ahmed 'Abdulhalîm 'Atiyye (Misır: el-Hey'etü'l- âmme li kusûri's-sikâfe, 2002), 141-156. 
letlerinin tamamında değil de özellikle Mısır'da doğmuş olmasının kendisini hayrete düşürdüğünü dile getirir. Subhî̀ye göre Arap-İslam felsefesinin üstatları zikredilecek olsa Zeki Necip ve Bedevî̀yi aşabilecek hiçbir şahıs asla bulunamazdı. Tüm bu bilgilerin ötesinde Subhî, Bedevî̀nin filozofluğuna yazdığ 1 metinlere işaret ederek delil getirir. ${ }^{39}$

$$
\text { el-Fikrü's-siyâsi fi'l-İslâm beyne'l-mâzî ve'l-hâdır ve tetallu' 'ât } 40
$$

\section{Mısru'l-kadìm ve neşetë̈t-tıb41}

'Kadîm Misır ve Tibbın Doğuşu' isimli bu metinde Subhî dört iddiayı ön plana çıkarır: 1] Bütün ilimlerin menşeini Yunan'a dayandırma düşüncesi hatalıdır. 2] Tıp kadîm Mısırdan doğmuş ve yayılmıştır. 3] Ameliyat, tıbbın en gelişmiş dalıdır. 4] Ameliyat ve anatomi ilimlerinin gelişiminde mumyalamanın rolü vardır.

Hivâr ma 'a sadîk 'ömer 'Âtıf el-'Irâkî Râiden li'l-fikri'l- 'akli't-tenvîrî42

\subsection{Makale}

en-Nazariyyâtu's-siyâsiyye leda'l-firaki'l-İslâmiyyin ${ }^{43}$

el-Likâ' beyne'l- 'âlem ve'd-din 44

et-Tasavvuf îcâbiyyatubu ve selbiyyâtubu 45

'Akîdetül-mehdi'l-müntazır min manzûri felsefi ${ }^{46}$

Itticahâtül-felsefeti'l-İslâmiyye fil- 'alemi'l- 'arabî fi'l-karni'l- 'isrîn 47

39 Subhî, “'Âbdurrahman Bedevî: Feylesûfu'l-mütevahhid”, 142.

40 Ahmed Mahmûd Subhî, "el-Fikrü's-siyâsi fi'l-İslâm beyne'l-mâzî ve'l-hâdır ve tetallu ât", Fuâd Zekeriyyâ Bâhisen ve müsekkafen ve nâkiden: Kitâbun tizkârîyyun, ed. 'Abdullah Ömer (Kuveyt: Câmi atu Kuveyt, 1998), 285-321.

41 Ahmed Mahmûd Subhî, "Misru'l-kadîm ve neş'etü't-tıb”, Terôîk Tavîl Müfekkiren 'Arabiyyen ve râiden li'l-felsefeti'l hulkiyye: Buhûsun 'anhu ve dirâsâtün mehdâtün, ed. 'Âtıf el- 'Irâkî (Kâhire: el-Hey'etü'l- âmme li şuûni'l-mutâbii '1-emîriyye, 2004), 195-210.

42 Ahmed Mahmûd Subhî, "Hivâr ma'a sadîk 'ömer 'Âtıf el- 'Irâkî Râiden li'l-fikri'l- 'akli'ttenvîr̂̀', 'Âtrf el-'Irâkî: Feylesûfen 'arabiyyen ve râiden li'l-itticâbi'l-'akli't-tenvîrî kitâbun tizkâriyyun, ed. Fuâd Zekeriyyâ (İskenderiyye: Dârü'l-Vefâ, 2002), 93-106.

43 Ahmed Mahmûd Subhî, “en-Nazariyyâtu's-siyâsiyye leda'l-firaki'l-İslâmiyyîn”, Mecelletü 'âlemi'l-fikr 2 (1993), 133-175.

44 Ahmed Mahmûd Subhî, "el-Likâ' beyne'l- 'âlem ve'd-din”, Mecelletü Kâhire 6 (1985), 21.

45 Subhî, "et-Tasavvuf îcâbiyyatuhu ve selbiyyâtuhu".

46 Ahmed Mahmûd Subhî, “'Akîdetü'l-mehdi'l-müntazır min manzûrin felsefîyyin”, Mecelletü Kâhire 81 (1988), 17-20.

${ }^{47}$ Ahmed Mahmûd Subhî, "İtticahâtü'l-felsefeti'l-İslâmiyye fi'l- 'alemi'l- arabî fi'l-karni'l- 
el-Kîmyâ ve Câbir b. Hayyân 48

Asparta 49

Felsefe: Ubtun radî'a li’ş-şeri a em durretün lidîdin?50

Hasâisu tabi 'ati't-tasavouf 51

Beyne't-tasavouf ve 'ilm-i kelâm 52

Mülâbisâtü't-tasavouf ve tabi'atubu 53

Nakdu'l-mu'tezile li'l-felsefeti'l-Yûnânîyye 54

el-Hikmetül-ilabiyye fi'l ibtilâf 55

Beyne'l-insân ve'l-bürriyye 56

Heli'l-abkâmu'l-felsefe burhâniyyetun: Dirâsetün li mevzî̀ et-tevfîk beyne'd-din ve'l-felsefe 57

Beyne Dimokrâti Atinâ ve Diktâtûri Asparta 58

'işrîn”, Ve Hameleha'l-insân: Makâlâtün Felsefiyyetün, ed. Ahmed Mahmûd Subhî (Beyrut: Dârü'n-nahdati'l- 'arabiyye, 1997), 243-270.

48 Ahmed Mahmûd Subhî, "el-Kîmyâ ve Câbir b. Hayyân", Ve Hameleha'l-insân: Makâlâtün Felsefiyyetün, ed. Ahmed Mahmûd Subhî (Beyrut: Dârü'n-nahdati'l- 'arabiyye, 1997), 231-242.

49 Ahmed Mahmûd Subhî, "Asparta”, Ve Hameleba'l-insân: Makâlâtün Felsefiyyetün, ed. Ahmed Mahmûd Subhî (Beyrut: Dârü'n-nahdati'l- 'arabiyye, 1997), 224-230.

50 Ahmed Mahmûd Subhî, "Felsefe: Uhtun radî‘ a li'ş-şeri a em durretün lidûdin?”, Ve Hameleha'linsân: Makâlâtün Felsefiyyetün, ed. Ahmed Mahmûd Subhî (Beyrut: Dârün-nahdati'1'arabiyye, 1997), 159-170.

51 Ahmed Mahmûd Subhî, "Hasâisu tabi 'ati't-tasavvuf", Ve Hameleha'l-insân: Makâlâtün Felsefiyyetün, ed. Ahmed Mahmûd Subhî (Beyrut: Dârü’n-nahdati'l- 'arabiyye, 1997), 94-114.

52 Ahmed Mahmûd Subhî, "Beyne't-tasavvuf ve 'ilm-i kelâm”, Ve Hameleha'l-insân: Makâlâtün Felsefiyyetün, ed. Ahmed Mahmûd Subhî (Beyrut: Dârü'n-nahdati'l- 'arabiyye, 1997).

53 Ahmed Mahmûd Subhî, "Mülâbisâtü't-tasavvuf ve tabi 'atuhu",Ve Hameleha'l-insân: Makâlâtün Felsefiyyetün, ed. Ahmed Mahmûd Subhî (Beyrut: Dârü'n-nahdati'l- 'arabiyye, 1997), 49-82.

54 Ahmed Mahmûd Subhî, "Nakdu'l-mu'tezile li'l-felsefeti'l-Yûnânîyye", Ve Hameleha'l-insân: Makâlâtün Felsefiyyetün, ed. Ahmed Mahmûd Subhî (Beyrut: Dârü'n-nahdati'l-'arabiyye, 1997), 34-37.

55 Ahmed Mahmûd Subhî, "el-Hikmetü'l-ilahiyye fi'l ihtilâf”, Ve Hameleha'l-insân: Makâlâtün Felsefiyyetün, ed. Ahmed Mahmûd Subhî (Beyrut: Dârü’n-nahdati'l- arabiyye, 1997), 15-23.

56 Ahmed Mahmûd Subhî, "Beyne'l-insân ve'l-hürriyye”, Ve Hameleha'l-insân: Makâlâtün Felsefiyyetün, ed. Ahmed Mahmûd Subhî (Beyrut: Dârü’n-nahdati'1- 'arabiyye, 1997), 11-15.

57 Ahmed Mahmûd Subhî, "Heli'l-ahkâmu'l-felsefe burhâniyyetün: Dirâsetün li mevzû' ettevfik beyne'd-dîn ve'l-felsefe”, el-Feylesûf İbn Rüşd Müfekkiren 'Arabiyyen ve müerriban li'lfelsefe: Bubûsun 'anbu ve dirâsâtün mehdâtü ileyh, ed. 'Âtıf el- 'Irâkî (Kâhire: el-Meclisü'l-a 'a li's-sikâfeti lücneti'l-felsefe ve'1-ictimâ', 1993), 57-88.

58 Ahmed Mahmûd Subhî, "Beyne Dîmokrâti Atinâ ve Diktâtûri Asparta”, Yusuf Kerim Müfekkiren 'Arabiyyen ve müerriban li'l-felsefe: Buhûsun 'anhu ve dirâsâtün mebdâtü ileyh, ed. 'Âtıf el-'Irâkî (Kâhire: el-Meclisü'l-a la li’s-sikâfeti lücneti'l-felsefe ve'l-ictimâ', 2004), 199-215. 
Nahou 'ilm-i kelam cedîd: Dirâsetün nakdiyyetün li ba'di'l-müskilâti'lkilâsikiyye 59

Babsun tekvîniyyun fiș-şabsiyye: Abdâsu't-tufûle60

$B a$ 'du Cevânibi't-tecdîd fil-fikri'l-İslamî 61

İbnu'l-vezîr ve difầ 'ubu 'an ehli'l-hadîs 62

Beyne'l-felsefeti ve't-tıb 63

\section{4. Çeviri}

Fecrüll-'ilmi'l-hadîs el-İslâm 64

Tobby E. Huff'un The Rise of the Early Modern Science, Islam, China and the West isimli eserini ilk olarak Subhî tercüme etmiştir. Daha sonra Mahmûd Ğusfûr tarafından yeniden tercüme edilip basılmıştır.

\subsection{Tez}

Kitap başlığı altında Subhînnin yüksek lisans ve doktora tezlerine değinildiği için bu başlıkta Subhî̀nin danışmanlığını yaptığı çalışmalar hakkında bilgi verilecektir.

Ebû̀ Hanîfe en-Nu'mân ve ârâubu'l-kelâmiyye65

Subhî̀nin danışmanlığını yaptığı bu tez, İskenderiye Üniversitesi Edebiyat Fakültesi Felsefe Bölümü İslam Felsefesi sahasında 1999 yılında Şemsüddin Muhammed Abdullatif isimli öğrencisine yaptırdığı bir yüksek lisans tezidir. Ebû Hanîfe'nin kelâmî görüşlerinin ele alındığı çalışma altı bölümden müteşekkildir. İlk bölümde hayatı, eserleri, hocaları, öğrencileri

59 Ahmed Mahmûd Subhî, "Nahvu 'ilm-i kelam cedîd: Dirâsetün nakdiyyetün li ba 'di'1müşkilâti'l-kilâsikiyye”, Mecelletü'l-cem 'iyyeti'l-mısriyye 1 (1992), 23-61.

60 Ahmed Mahmûd Subhî, "Bahsun tekvîniyyun fi'ş-şahsiyye: Ahdâsu't-tufûle”, Mecelletü 'ilmu’nnefs 6/2 (1951), 233-251.

61 Ahmed Mahmûd Subhî, “Ba 'du Cevânibi't-tecdîd fi'l-fikri'l-İslamî”, Mecelletü külliyyeti’l-âdâb 5 (1973), 51-80.

62 Ahmed Mahmûd Subhî, "İbnu'l-vezîr ve difâ 'uhu 'an ehli'l-hadîs", Mecelletü külliyyeti'l-âdâb 3 (1981), 203-218.

63 Ahmed Mahmûd Subhî, "Beyne'l-felsefeti ve't-tıb”, El-Fikru'l- 'arabî 12/63 (1991), 14-45.

64 Tobby E. Huff, Fecrü'l- 'ilmi'l-hadîs el-İslâm, es-Sìn, el-Ğarb, çev. Ahmed Mahmûd Subhî (Kuveyt: el-Meclisü'l-vatanî li's-sikâfeti ve'l-fünûn ve'l-âdâb, 1997).

65 Şemsüddin Muhammed Abdullatîf, Ebû Hanîfe en-Nu'mân ve ârâubu'l-kelâmiyye (Beyrut: İskenderiye Üniversitesi, Yüksek Lisans Tezi, 1999). 
ve Ebû Hanîfe'nin yaşadığı dönemdeki ilmî muhît ile kültür konularına yer verilir. İkinci bölümde Ebû Hanîfe'nin kullandığı metotlar üzerinden genel ilmî yaklaşımı ortaya koyulur. Daha sonraki bölümlerde sırasıyla zatsıfat, cebr ve ihtiyar, nübüvvet ve iman konuları işlenir. Son olarak Ebû Hanîfe'nin İslâmî firkalara dair nasıl bir konumu olduğu izah edilir.

el-İlâbiyyât 'inde müfekkirişs-şi ati'l-İsma 'iliyye fil-karneyni'r-râbî‘ ve'lbâmisil-bicriyeyn 66

Subhînin Abdülfettâh Ahmed Celal ile birlikte danışmanlığını yaptığ1 bu tez Şiî düşünürler üzerinden ilahiyat konularını inceleyen bir doktora tezidir.

Aliyâtü'l- 'almeneti ve betru'z-zâti'l-insâniyye67

'Sekülerleşme Mekanizmaları ve İnsânî Özün Yok Oluşu' isimli çalışma, Subhî’nin Muhammed Kâsım ile danışmanlığını birlikte yürüttüğü doktora tezidir. Beyrut Üniversitesi Edebiyat Fakültesi Felsefe Bölümü alanında Hişam Hüseyin Yunus tarafından hazırlanan tez 2002 yılında savunulmuştur.

\subsection{Hakkında Yapılan Çalışmalar}

Subbî 'Ahmed' Siretün Fikriyyetün ve nümùzecu li's-sıdk fil-hayâti ve'lfelsefeti 68

2016 yılında felsefî yazılar isimli bir dergide neşredilen bu makalede Muhammed Ramazan, Subhînnin hayat tarzında ve felsefe anlayışında mümtaz bir şahsiyet olduğunu ifade eder. Metinde, Subhînnin hayatı kısaca anlatılır ve belli başlı eserleri genel hatlarıyla incelenir.

en-Nüz'atün-nakdiyye fi fikri Abmed Mabmûd Subhî dirâsetün tablîliyyetün nakdiyyetün 69

2020 y1lında Mansûr Üniversitesi Edebiyat Fakültesi Lisansüstü Araş-

66 Şâdiye Enver Ahmed es-S1fâtî, el-İlâbiyyât 'inde müfekkiriş̧-şi ati'l-İsma 'iliyye fi'l-karneyni'rrâbî' ve'l-hâmisi'l-hicreyeyn (Kâhire: Mansûr Üniversitesi, Doktora Tezi, 1988).

${ }^{67}$ Hişâm Hüseyin Yunus, Aliyâtü̈l- 'almeneti ve betru'z-zâti'l-insâniyye (Beyrut: Beyrut Üniversitesi, Doktora Tezi, 2002).

68 Muhammed Ramazan Bistâvîsî, "Subhî 'Ahmed' Siretün Fikriyyetün ve nümûzecu li’s-sıdk fi'l-hayâti ve'l-felsefeti”, Evrâkun Felsefiyyetun 50 (2016), 249-276.

${ }^{69}$ Ahmed Îsâ YusufAli, en-Nüz 'atü'n-nakdiyyefifikriAhmed Mahmûd Subhî dirâsetün tablìliyyetün nakdiyyetün (Kâhire: Mansûr Üniversitesi, Doktora Tezi, 2020). 
tırmaları Enstitüsü Felsefe Bölümünde yapılan bu doktora tezi Subhî hakkında yapılan ilk tez hüviyetini taşımaktadır. Ahmed İsa Yusuf Ali tarafından yapılan çalışmanın danı̧̧manlığını Seyyid Muhammed Abdurrahman ve Hişam Ahmed Muhammed yürütmüştür.

\section{Buhîsun ve dirâsâtün felsefyyetün: Mehdâtü ile'l-Ahmed Mahmûd Subhî 70}

1997 yılında yayımlanan bu çalışma İskenderiye Üniversitesi Edebiyat Fakültesi Felsefe bölümü ailesinin bir ferdi olan Subhî hakkında yazılmıştır. İthaf, anma ve hatıra kitap literatürüne giren bu tür metinlerde yazarın entelektüel hayata katkısı, düşündürdükleri yazılır. Bu adeta dâr-1 bekâya göçen düşünürlere yapılan son bir görevdir.

\section{Hâulâi'l-müsakkafûn ve fikrubumu'l-islâbî 71}

2018 yılında Seyyid Abdüssettâr Meyhûb tarafindan kaleme alınan eserde Muhammed Abduh, Zeki Necip Mahmûd, Ahmed Mahmûd Subhî, Fuat Zekeriyya ve Atıf el-Irâkî gibi düşünürlerin yenilikçi görüşleri etraflıca ortaya konulur. Meyhûb’a göre Subhî bazı geleneksel kabullerin altını oyarak bir İslam kültürü ikame edebilmek için kelâm ilminden çıkardığı bir metotla vaka ilmini kuran ve bu ilmin ilk ilkelerini vaz eden kişidir.

\section{Ahmed Mahmûd Subhî Râid et-tecdî̀ fi fikri'l-İslâm 72}

Subhînin vefatının ardından 5 yıl sonra 2009 yılında talebesi ve aynı zamanda İskenderiye Üniversitesi Edebiyat Fakültesi Felsefe Bölümü başkanlığ1 da yapmış olan Safâ Abdusselâm Ca'fer'in editörlüğünü yaptığ1 eserdir. Bir anma kitabı olarak yazılan bu tür eserlerin Misır özelinde bir gelenek haline geldiğini söylemek mümkündür. Subhînin kitap bölümü olarak yazmış olduğu metinler ekseriyetle bu tür anma kitapları içerisindedir.

\section{Fi'l-fikri'l-İslâmîl-muâsır: Makâlâtün Tizkâriyyetün 73}

İslam düşüncesini yaptıkları akademik çalışmalarla inşa eden düşünürler için yazılmış bir anma kitabıdır. Mustafa Abdurrâzık, Ali Abdurrâzık,

\footnotetext{
70 Mâhir Abdulkadir Muhammed Ali, Buhûsun ve dirâsâtün felsefiyyetün: Mehdâtü ile'l-Ahmed Mahmûd Subhî (Kâhire: Dâru'l-ma 'rifeti'l-câmi 'iyyeti, 1997).

${ }^{71}$ Meyhûb, Haulâi'l-müsakkafûn ve fikrubumu'l-islâbî.

72 Safâ Abdusselam Ca'fer (ed.), Ahmed Mahmûd Subhî Râid et-tecdî̀ fi fikri'l-İslâm: Kitabün tizkâr li 'ilmi min ceyli'r-revâd (b.y.: el-Hudrî li't-tibâ', 2009).

73 İbrahim Muhammed Türkî, Fi'l-fikri'l-İslâmî'l-mu 'âstr: Makâlâtün Tizkâriyyetün (b.y.: Dâru'lkütübi'l-kânûniyye, 2009).
} 
Bedevî, 'Âtıf el- 'Irâkî ve Subhî genel hatlarıyla fikirleri verilerek tanıtılır. Eserde Subhînnin de çeşitli konular hakkındaki fikirleri derlenmiştir. Bunların başlıklarını vermekle yetineceğiz: 'Kadın-erkek eşitliği ve İslam'da kadının hakları meselesi', 'İslam medeniyetinde siyasi yönün zayıflı̆̆', 'İslamdaki hukuk düzeni teokratik değildir', 'İslam düşüncesinde din-siyaset ilişkisi', 'İslam siyaset düşüncesinin yenilenmesi mümkün müdür?’, 'En erdemli demokratik sistem', 'İslam’ın bakı̧̧ıla demokrasi'.

\section{3. İslam Düşüncesine Katkısı}

Subhî̀ye göre İslam düşüncesine bütüncül bakmak elzemdir. Zira sahih ve cârî yorumlar ancak farklı disiplinlerin gözüyle problemler alanına bakıldığında mümkün olur. Subhî̀nin nazarında bu yaklaşım sadece el-Felsefetül-ablâkiyye fi fikri'l-İslâm eseri altında işlenmese de en net bir şekilde burada tetkik edilmiştir, denilebilir. Aynı zamanda eser, tümevarım ve tümdengelim metotlarını uyguladığı birçok eserinden sadece biridir. Subhî bu iki metodu kullanarak ahlâk bahsinde sırasıyla kelâm, tasavvuf ve akabinde uzlaştırıcı ekoller olarak zikrettiği İhvân-1 Safâ ve İbn Miskeveyh'in dahil olduğu felsefe disiplini üzerinden mukayeseli bir okuma ile İslam düşüncesinin bütüncül okunmasının gerekliliğine vurgu yapar.

Subhînnin bahsi geçen doktora tezini diğerlerinden ayıran yön, hiç şüphesiz disiplinler arası bir okumayla İslam ahlâk düşüncesine yaklaşmasıdır. Bir metot olarak bunu danı̧̧man hocası Ali Sâmî en-Neşşâr'dan aldığını söyleyebiliriz. Neşşâr'ın da aynı yaklaşımı kendi hocası Mustafa Abdurrâzık'tan aldığı görülür. Bu üç düşünürün yaklaşımları eserlerine bakıldığında daha net bir şekilde ortaya konulabilir. Sözgelimi Mustafa Abdurrâz1k ${ }^{74}$, Tembîd li târibi'l-felsefetil'-islâmiyye 75 eserinde salt kelâm ve felsefe ile sınırlı kalmayıp usulü fıkıh disiplinini de işin içerisine kattığı bir kurguyla İslam düşüncesini ele alır. Subhî 1960-1980 yılları arasında modern Arap dünyasında felsefenin serüvenini ortaya koyduğu bir yazısında

\footnotetext{
74 Saîd Murâd, "Mustafa Abdürrâzık”, TDV İslam Ansiklopedisi (İstanbul: Türkiye Diyanet Vakfı Yayınları, 2006), 31/285-286.

75 Mustafa Abdurrâzık, Tembìd li târibi'l-felsefeti'l-islâmiyye (Kâhire: Lecnetü't-te'lif ve't-tercüme ve'n-neşr, 1944).
} 
Mustafa Abdurrâzık'in bu metoduna işaret eder. Subhî̀ye göre Abdurrâzık, ilmî bir araştırmaya girişmeden önce felsefî bir okumanın ardından fikıh usûlü ilminin geldiğini ve bu iki ilmin İslam'daki iki temel ilim olduğunu kabul eder. Nitekim Tembîd li târibi'l-felsefetil-islâmiyye isimli eserini bu iddialarını ispatlar nitelikte fikıh usulü, felsefe ve kelâmın da dahil olduğu ekollerin problem ve metotlarıly mecz ederek yazmıştır. ${ }^{76}$ Kurun'un değindiği üzere Mustafa Abdurrâzık'in bahsi geçen eseri İslam felsefesinin Batıdaki felsefe anlayışlarından farklı olduğu ve farklı bir şekilde ele alınması gerektiği konusunu işler. Aynı zamanda Abdurrâzık’n okuması, İslam düşüncesine dair farklı bir paradigmanın var olabileceğini ve inşa edilebileceğini gösterme gayretindedir. 77

Mustafa Abdurrâzık'ın öğrencisi Neşşâr da hem bütüncül yaklaşımın bir örneğini hem de mukayeseli bir İslam düşünce tarihi okumasını Menâbicül-bahs 'inde müfekkiri'l-İslâm ${ }^{78}$ isimli eserinde yapar. Burada mantık ilmini Aristocu şekliyle İslam dünyasında kabul etmeyen ve alternatif bir bakış açısı getiren İbn Teymiyye özelinde bir fikir inşa eder. Eserin başından sonuna kadar mantık, kelâm ve usul-i fikıh kavramlarının mukayeseli ve iç içe kullanımı Neşşâr'ın hocasından kazanmış olduğu perspektifi yansıtır. Dolayısıyla yukarıda işaret ettiğimiz üzere Subhînnin disiplinler arası bir yaklaşımla ahlâk sahasına eğilmesinin arka planında Mustafa Abdurrâzık ve Neş̧̧âr gibi isimler etrafinda şekillenmiş ilmî bir geleneğin varlı̆̆ 1 yatar.

Subhî’nin bağlı bulunduğu ilmî geleneği sürdürdüğünü rahatlıkla iddia edebilmemize imkân tanıyan en net metin bahsi geçtiği üzere onun doktora tezidir. Bu çalışmanın ahlâk felsefesi araştırmalarına nasıl bir ufuk kazandırdığını bir başka çalışmaya erteleyerek sadece çalışmada takip ettiği metodun İslam düşüncesine sunduğu katkı üzerinde duracağız.

Subhî'nin en önemli tespitlerinden bir tanesi, 'felsefî ahlâk çalışmalarında İslam düşüncesinin en temel iki ekolü denilebilecek Mu'tezile ve

\footnotetext{
76 Subhî, “İtticahâtü'l-felsefeti'l-İslâmiyye fi'l-vatani'l- arabi (1960-1980)”, 103.

77 İsmail Kurun, İslam Felsefe Taribinin Eleştirel Yeniden-İnșası: İbn Sina Epistemolojisi Örneği (Ankara: Ankara Üniversitesi, Doktora Tezi, 2021), 45-46.

78 Ali Sâmî Neşşâr, Menâhicül-babs 'inde müfekkiri'l-İslâm (Beyrut: Dârü'n-nahdati'l-'arabiyye, 1984).
} 
Sûfilerin metinlerinin göz ardı edildiği' gerçeğine dayanır. ${ }^{79}$ Diğer bir ifadeyle Subhî̀nin yaptığı şey birbirinden kopuk alanlar olarak gözüken ve müstakil birer disiplin haline gelen tasavvuf, felsefe ve kelâmın esasında iç içe olduğunu gösterme gayretidir. Bu değerlendirmenin felsefî ahlâk araştırmalarına yeni ufuklar ve imkanlar kazandıracağına şüphe yoktur. ${ }^{80}$

Doktora tezinin yanı sıra birçok metninde tekrar tekrar bu tavrı görürüz. Subhî, yetmiş üç firka görüşünü ispat için ortaya konulan İslam düşüncesindeki çabaların düşünceyi parçaladığını ve onun bütünlüğünü kaybettirdiğini söyler. Ona göre bu tür çabalar içerisinde yirmi firka olarak resmedilen Mu'tezile, ittifakla beş ilke üzerinde uzlaşmıştır. Dolayısıyla Subhî, sûfîlerin de kendi içerisinde farklılıkları olmasına rağmen onları uzlaştıran noktaların varlığının tasavvuf denilen çatıyı inşa ettiğini söyler. $\mathrm{Bu}$ durum her İslamî firka için geçerlidir. Yani bu firkalar kendi içlerinde ayrıntı sayılabilecek ihtilafları görmezden gelerek genel esaslar üzerinde ittifak ederler. 81 Görüldüğü üzere Subhî İslam düşüncesine bütüncül bir şekilde yaklaşmanın önündeki en büyük engelin firkalara bölünme olduğunu dile getirir. Meyhûb’un ifadesiyle Subhî düşüncesinde, ihtilaf bir sorun teşkil etmez. Aksine İslam düşüncesine zenginlik verir ve İslam medeniyetini parlak bir medeniyet haline getirir. ${ }^{82}$

Subhî bütün ayrıntılarıyla düşünürlerin görüşlerine değinmez. Zira problem ve çözüm odaklı meseleye yaklaştığından ayrıntılarda boğulmayı gereksiz bulur. Subhî'nin gayesi sayısız ihtilaf içerisinde asıl meseleyi ıskalamamaktır. Buna örnek olarak sûfî geleneğin belli bir noktayla sınırland1ğına işaret eder: 'Bilgi ve özgürlük problemlerinin araştırılmasında bir yer teşkil etmesi gereken sûfîlerin görüşleri, İslâm tasavvufunun araştırılması sadedinde gündeme gelen problemlerin ortasında kaybolup gitti.'83 Aynı

79 Türkiye'de yapılan bu tür çalışmalara örnek olarak bk. Sami Şekeroğlu, Mâtürîdî’de Ablak E̋ Felsefî Bir Betimleme (Ankara: Ankara Okulu Yayınları, 2010); Abdunnâsır Süt, Muİtezile ve Ablak \& Kadı Abdülcebbar Örneği (İstanbul: İz Yayınc1lı, 2016).

$80 \mathrm{Bu}$ tarz bir kurgu ve muhtevayla ahlâk felsefesi çalışmalarına yeni bir nefes veren örnek bir çalışma için bk. Yunus Cengiz, Doğa ve Öznellik Cahız’n Ahlak Düşüncesi (İstanbul: Klasik Yayınları, 2015).

81 Subhî, el-Felsefetül-ablâkiyye fi fikri'l-İslâm el-'akliyyûn ve'z-zevkiyyûn evi'n-nazar ve'l- 'amel, 31.

82 Meyhûb, Haulâi'l-müsakkafûn ve fikrubumu'l-islâbî, 122.

83 Subhî, el-Felsefetül-ablâkiyye fi fikri'l-İslâm el-'akliyyûn ve'z-zevkiyyûn evi'n-nazar ve'l- 'amel, 32. 
durum $\mathrm{Mu}$ 'tezile için de geçerlidir. Zira onların ahlâka dair görüşleri de sadece hüsün-kubûh konusuna indirgenmektedir.

Subhînnin disiplinlerarası okuma yaptığı önemli başlıklardan birisi, Sûfî gelenek içerisinde sürekli tartışılan konularda kendini gösterir. Genellikle tasavvufa karşı menfi yorumların yapıldığı şeyh-mürid ilişkisi buna örnek verilebilir. Subhî şeyh-mürid ilişkisinin sûfî gelenekte inşa edilme sürecini anlattığ 1 yerde psikolog ve psikiyatrların hastalarıyla olan ilişkilerinden bahseder. Burada hem kuşatıcı bir bakışla bakar hem de ikircikli bir tutumun varlığına işaret eder. Konuya getirdiği kuşatıcı bakış açısını tasavvuf-psikanaliz arasında ilişki kurarak gösterir. İkircikli tutum, psikoloğun hastasıyla olan ilişkisinde her türlü sırrını bilmesi sorun teşkil etmezken, şeyh-mürid ilişkisinde şeyhin müridin sırrını bilmesinin çok büyük bir problemmiş gibi sunulmasıdır. ${ }^{84}$

Subhînnin İslam düşüncesine katkısının boyutu kullandığı metotta daha belirgindir. O bir metot olarak aklî delile daha fazla önem vermekle birlikte aklı ve nakli birlikte ele alır. Bunun bariz örneği kendi doktora tezinde izlediği yoldur. Hatırlanacağı üzere önce akılcıların [Mu'tezile] sonra tecrübecilerin [sûfîler] görüşlerine yer vermiş, en son aklı ve tecrübeyi uzlaşt1ran İhvân-1 Safâ ve İbn Miskeveyh üzerinde durmuştur. Ancak metodunda akılcılığın ağır bastığını da ifade etmemiz gerekir: 'İnançlarını doğrulayabilme adına modern dönem Müslümanları, manevî bir rızık ve aklî bir güç sunabilmek için Müslüman âlimlerin varlığına nasıl muhtaçsa aynı şekilde Müslümanların yüzyıllardır omzunda taşıdığı yükten kurtulmak için ihyâ düşüncesinin damarlarında i'tizâl ruhunun dolaştırılması gerektiğini de akılda tutmaları gerekir.' 85

Subhînnin Mu'tezile başta olmak üzere tüm İslami fırkalara karşı okuyucusuna kazandırmak istediği bir bakış açısı ve yöntemi vardır ve bu amacını bazı ilkeler inşa ederek göstermeye çalışır. İlk olarak o, İslam felsefesinde araştırmacıların iki gruba bölündüklerinin altını çizer; yani bir grup araştırmacı bu düşünce geleneğini özgün görürken, diğer bir grup Yunan’la

84 Subhî, el-Felsefetül-ahlâkiyye fi fikri'l-İslâm el-'akliyyûn ve'z-zevkiyyûn evi'n-nazar ve'l- 'amel, 240-251.

85 Subhî, el-Felsefetü'l-ablâkiyye fi fikri'l-İslâm el-' akliyyûn ve'z-zevkiyyûn evi'n-nazar ve'l- amel, 320-321. 
başlatıp onu Yunan'a dayandırır. Subhî kelâm bağlamında tartışılan birçok problemin İslam felsefesini özgün kılan noktalar barındırdığından hareketle kendisini ilk grup içerisinde değerlendirir. Ayriyeten altını çizdiği ilke, her medeniyetin kendine özgü bir tabiata her firkanın da kendine özgü özelliklere sahip olduğu görüşüne dayanır. Bir diğer ilke, her firka doğuşundan itibaren kökenleri ve önde gelen temsilcileri ile bütüncül bir sistem içerisinde ele alınması gerektiği hakkındadır. Ayrıca Subhî, bu bütüncül sistemin salt tarihsel bir anlatıya dönüşme tehlikesi hakkında uyarılarda da bulunur. Subhî son ilkeyi bir tespit yaparak ortaya koyar: Ona göre İslam düşüncesi araştırmacıları ya geleneği ihya etme çabası içerisine girmişler ya da geçmişi günümüzün değer ve tasavvurlarıyla ele almışlardır. Oysa İslam düşüncesi medeniyetlerin bıraktıkları tesirler bağlamıyla sınırlandırılamaz. Zira İslam düşüncesi aynı zamanda kalplerde yaşayan bir dini mirasa taalluk eder. Dolayısıyla son ilke bağlamında İslam düşüncesi ne geçmişe ne de günümüze hapsedilmelidir. 86

Subhî̀nin İslam düşüncesine yaklaşımında bariz şekilde görülen bir diğer nokta kavramların izini sürmesidir. O kavramları farklı ekoller etrafında mukayeseli bir şekilde anlamaya gayret eder. Mesela Subhî imamet kavramını Şiî gelenek içerisinde izah ettikten sonra Mu'tezile ve Şîa; tasavvuf ve Şîa, İslam felsefesi ile Şîa arasında mukayeseler yaparak bütüncül ve kapsayıcı bir bakış getirmeye çalışır. ${ }^{87}$

Subhînnin yukarıda ifade edilen tavrı, diğer bir ifadeyle ilmî tutumu birçok eserine sirayet etmiştir. Bu eserlerinden biri olan İmâmu'l-müctehid Yahya b. Hamza ve ârâubu'l-kelâmiyye isimli kitabında kelâmi görüşleri ve tartı̧̧maları zikretmekle beraber bu konuların tazammun ettiği amelî yöne yani ahlâka da genişçe değinir. Dolayısıyla düşünürün zihninde tabiri caizse sürekli bir disiplinlerarası okuma ve mukayese deverân etmektedir.

Bu deverânın diğer bir örneği çift yazarlı kaleme alınan Fi Felsefeti't-tıp eseridir. Tıp felsefesine dair birçok tartışma metinde yer almasına rağmen bizi ilgilendiren Subhî’nin disiplinlerarası okumasının burada da karşımıza

86 Subhî, Fi 'ilmi kelâm dirâsetün felsefiyyetün li ârâi'l-firaki'l-İslâmiyyeti fi usûli'd-dîn: Mu'tezile, 1/9-12.

87 Subhî, Nazariyyetül-imâmiyye ledâ eş-ş̂̀ 'ati'l-isnâ 'aşeriyye tablîlün felsefiyyetün li’l- 'akîde, 449. 
çıkmasıdır. Eserin ikinci bölümünde Arap-İslam tıbbının Yunan tıbbının bir devamı olup olmadığ 1 tartışılır. Yazarların iddiasına göre her ne kadar Yunan tıbbının birtakım şekilleri İslam tıbbı içerisinde yer alsa da İslam Arap tıbbı kendine has noktalar barındırmaktadır. Bunlar İslam Arap tıbbının kelâmî temelleridir ve psikiyatride tasavvufun rolünü ispatlamaya çalışan iddialardır. 88

Yukarıda zikredilen birçok örnekte Subhînnin disiplinlerarası okuma yapma fikrine ne kadar bağlı olduğunu gösterdik. Ancak söz konusu örneklerin dışında Subhî, ilk bakışta birbirine oldukça uzak gibi görünen disiplinleri de mukayese eder. Mesela, Beyne't-te'rîh ve't-tahdîs adlı eserinde hadis ve tarih disiplinlerini tüm farklılıklarına rağmen mukayeseli bir şekilde inceler. O'nun temel iddiası doğa bilimleri ve matematiksel bilimlerin belli bir metot altında sıralandıkları gibi söz konusu iki disiplini de metodik olarak mukayese etmenin ve bu iki disiplinin benzerliklerini bulmanın mümkün olduğu yönündedir. ${ }^{89}$

\section{Sonuç}

Ahmed Mahmûd Subhîyi ve düşüncesini genel hatlarıyla ortaya koyma azminde olduğumuz bu çalışma, onun hakkında yapılacak çalışmalara bir mukaddime olabilme mahiyetini taşır.

Velûd bir yazar olmasının yanı sıra Subhî, belli bir gelenek içerisinde yetişmiştir. Subhî̀yi mercek altına almamızın en önemli sebebi, bu geleneğin sürdürücüsü olmasıdır. $\mathrm{O}$, bu yolda selefleri olan Mustafa Abdurrâzık ve Ali Sâmî en-Neşşâr'ı takip etmiştir. Seleflerinin kelâm ve felsefe sahasında ortaya koydukları düşünme biçimini ahlâk, tarih felsefesi ve tıp felsefesi gibi birçok sahada tatbik etmeye çalı̧̧mıştır.

Subhînnin nihai gayesinin insanı ilgilendiren her düşünme biçiminin veya ilmî sahanın birbiriyle irtibatlı olduğunu savunmak olduğunu söyleyebiliriz. Bu irtibat yoksa, Subhî nazarında bunun sebebi böyle bir okuma yapılmıyor olmasındandır. Tip felsefesi isimli eserinde de bariz şekilde göze çarpan şekliyle psikiyatri ve tasavvuf arasında bir yol bulması buna esaslı bir örnektir. 
Hulâsâ Subhî’nin eserlerinde gösterdiği bu metot, tavır veya yaklaşım; İslam düşüncesi sahasında araştırma yapan ve belli isim ve problemlerle kendilerini sınırlayan araştırmacılara yeni bir ufuk ve okuma biçimi sunmaktadır.

Subhî’nin İslam düşüncesine dair araştırmalara yeni bir soluk getireceğini düşünüyoruz. Bu ancak onun metodik ve disiplinlerarası bakış açısının gün yüzüne çıarılmasıyla mümkündür. Genel bir çerçeve çizdiğimiz bu çalışma Subhî hakkında yapılacak tez ve makale gibi akademik çalışmalarla ancak kendisini kemâle erdirebilecektir.

\section{Kaynakça}

Abdullatîf, Şemsüddin Muhammed. Ebû Hanîfe en-Nu'mân ve ârâubu'l-kelâmiyye. Beyrut: İskenderiye Üniversitesi, Yüksek Lisans Tezi, 1999.

Abdurrâzık, Mustafa. Tembîd li târibi'l-felsefeti'l-islâmiyye. Kâhire: Lecnetü't-te'lif ve't-tercüme ve'n-neşr, 1944.

Ali, Ahmed Îsâ Yusuf. en-Nüz'atün-nakdiyye fi fikri Ahmed Mahmûd Subb̂̀ dirâsetün tablilliyyetün nakdiyyetün. Kâhire: Mansûr Üniversitesi, Doktora Tezi, 2020.

Ali, Mâhir Abdulkadir Muhammed. Buhûsun ve dirâsâtün felsefiyyetün: Mehdâtü ile'l-Ahmed Mahmûd Subbî. Kâhire: Dâru'l-macrifeti'l-câmi' iyyeti, 1997.

Anay, Harun. “Çağdaş Arap Düşüncesi Üzerine”. Divan: Disiplinlerarası Galısmalar Dergisi 10 (2001), 1-88.

Anay, Harun. "İslam Düşüncesi ve Batı Felsefesiyle İlgili Arapça Yüksek Lisans ve Doktora Tezleri”. Divan: Disiplinlerarası Callsmalar Dergisi 10 (2001), 239-305.

Attar, Mariam. Islamic Ethics: Divine Command Theory in Arabo-Islamic Thought. New York London: Routledge, 2010.

Attar, Meryem. İslam Ablakı İslam Düșüncesinde İlâhı̂ Emir Teorisi. ed. Muammer İskenderoğlu. çev. Enver Şahin vd. İstanbul: Litera Yayıncılık, 2019.

Bistâvîsî, Muhammed Ramazan. "Subhî 'Ahmed’ Siretün Fikriyyetün ve nümûzecu li's-sıdk fi'l-hayâti ve'l-felsefeti”. Evrâkun Felsefyyetun 50 (2016), 249-276.

Ca'fer, Safâ Abdusselam (ed.). Ahmed Mahmûd Subhî Râid et-tecdîd fi fikri'lİslâm: Kitabün tizkâr li 'ilmi min ceyli'r-revâd. b.y.: el-Hudrî li't-tibâc, 2009. 
Cengiz, Yunus. Doğa ve Öznellik Cahız’n Ablak Düşüncesi. İstanbul: Klasik Yayınlar1, 2015.

Çelebi, İlyas. "Mu'tezile”. TDV İslam Ansiklopedisi. 31/391-401. İstanbul: Türkiye Diyanet Vakf1 Yayınları, 2006.

Fettâh, İrfan Abdülhamîd. “Ebü'l-Hasan Eş’arî”. 444-447. İstanbul: Türkiye Diyanet Vakf1 Yayınları, 1995.

Gazzâvî, Züheyr. “et-Tiyâru'l-istirdâdî'l-felsefiyyi'l-mıriyyi ve dirâsetü’ş şi'ati'limâmiyye isnâ 'aşeriyye”. Mecelletül-minhâc 2 (1996), 74-109.

Gökalp, Yusuf. “Zeydiyye”. TDV İslam Ansiklopedisi. 44/328-331. İstanbul: Türkiye Diyanet Vakfı Yayınları, 2013.

Hamûd, Yahya - Subhî, Ahmed Mahmûd. "Fi Felsefeti't-târîh". El-Fikru'l-‘arabî 4/28 (1982), 222-233.

Huff, Tobby E. Fecrü'l-ilmi'l-hadîs el-İslâm, es-Sîn, el-Ğarb. çev. Ahmed Mahmûd Subhî. Kuveyt: el-Meclisü'l-vatanî li's-sikâfeti ve'l-fünûn ve'l-âdâb, 1997.

Kurun, İsmail. İslam Felsefe Taribinin Eleştirel Yeniden-İnşası: İbn Sina Epistemolojisi Örneği. Ankara: Ankara Üniversitesi, Doktora Tezi, 2021.

Meyhûb, Seyyid Abdüssettâr. Haulâi'l-müsakkafûn ve fikrubumu'l-islâbî. Santa Anita: Mektebetü's-sikâfeti'd-dîniyye, 2018.

Murâd, Saîd. “Ali Sâmî Neşşâr”. TDV İslam Ansiklopedisi. 33/22-24. İstanbul: Türkiye Diyanet Vakfı Yayınları, 2007.

Murâd, Saîd. "Mustafa Abdürrâzık". TDV İslam Ansiklopedisi. 31/285-286. İstanbul: Türkiye Diyanet Vakfi Yayınları, 2006.

Neşşâr, Ali Sâmî. Menâbicül-bahs 'inde müfekkiri'l-İslâm. Beyrut: Dârü'nnahdati'l-'arabiyye, 1984.

Neş̧̧̂ิr, Ali Sâmî - Subhî, Ahmed Mahmûd. Neş’etül-fikri'l-felsefiyyi 'inde Yunan. Beyrut: Dârü'n-nahdati'l-'arabiyye, 1996.

Özturan, Hümeyra. "İslâm Ahlâk Çalışmalarının Dünü ve Bugününe Dair Bir İnceleme”. İslam Ablak Literatürü Ekoller ve Problemler. ed. Ömer Türker, Kübra Bilgin. 1-42. İstanbul: Nobel Yayın Dağıtım, 2016.

Sifâtî, Şâdiye Enver Ahmed es-. el-İlâhiyyât 'inde müfekkiri'ş-şi'ati'l-İsma'iliyye fi'l-karneyni'r-râbî‘ ve'l-hâmisi'l-hicreyeyn. Kâhire: Mansûr Üniversitesi, Doktora Tezi, 1988.

Subhî, Ahmed Mahmûd. "Asparta”. Ve Hameleha'l-insân: Makâlâtün Felsefiyyetün. 
ed. Ahmed Mahmûd Subhî. 224-230. Beyrut: Dârü’n-nahdati'l-‘arabiyye, 1997.

Subhî, Ahmed Mahmûd. "Bahsun tekvîniyyun fiş-şahsiyye: Ahdâsu't-tufûle”. Mecelletü 'ilmu'n-nefs 6/2 (1951), 233-251.

Subhî, Ahmed Mahmûd. “Ba`du Cevânibi't-tecdîd fi'l-fikri'l-İslamî”. Mecelletü külliyyeti'l-âdâb 5 (1973), 51-80.

Subhî, Ahmed Mahmûd. "Beyne Dîmokrâti Atinâ ve Diktâtûri Asparta”. Yusuf Kerim Müfekkiren 'Arabiyyen ve müerriban li'l-felsefe: Bubûsun 'anhu ve dirâsâtün mehdâtü ileyh. ed. 'Âtıf el-'Irâkî. 199-215. Kâhire: el-Meclisü'1a'la li’s-sikâfeti lücneti'l-felsefe ve'l-ictimâc, 2004.

Subhî, Ahmed Mahmûd. "Beyne'l-felsefeti ve't-tıb”. El-Fikru'l-'arabî 12/63 (1991), 14-45.

Subhî, Ahmed Mahmûd. “Beyne'l-insân ve'l-hürriyye”. Ve Hameleha'l-insân: Makâlâtün Felsefiyyetün. ed. Ahmed Mahmûd Subhî. 11-15. Beyrut: Dârü'n-nahdati'l-‘arabiyye, 1997.

Subhî, Ahmed Mahmûd. "Beyne't-tasavvuf ve cilm-i kelâm”. Ve Hameleha'l-insân: Makâlâtün Felsefiyyetün. ed. Ahmed Mahmûd Subhî. 82-94. Beyrut: Dârü'n-nahdati'l-'arabiyye, 1997.

Subhî, Ahmed Mahmûd. Beyne't-te’rîh ve't-tahdîs. İskenderiyye: Müessesetü'ssikâfeti'l-câmi'iyye, 1975.

Subhî, Ahmed Mahmûd. Cüzûru'l-irhâb fill-akîdeti'l-vahbâbiyye. b.y.: Dâr'unnasr, 2008.

Subhî, Ahmed Mahmûd. "Dirâsetün nakdiyyetün li ba'di'l-müşkilâti'l-kelâmiyye min manzûrin luğaviyyin mantıkiyyin”. Mahmûd Kâsım el-İnsân ve'lfeylesûf 1913-1973 Kitâbu’n tizkârî. ed. Hâmid Tâhir. 373-394. Kâhire: Mektebetü'l-Angolo el-misriyye, 1995.

Subhî, Ahmed Mahmûd. el-Bahreyn ve’d-da'va Îrân. İskenderiyye, 1963.

Subhî, Ahmed Mahmûd. el-Felsefetül-ablâkiyye fi fikri'l-İslâm el-‘akliyyûn ve'zzevkiyyûn evi'n-nazar ve'l-'amel. Kâhire: Dâru'1 Ma'ârif, 1983.

Subhî, Ahmed Mahmûd. “el-Fikrü’s-siyâsi fi'l-İslâm beyne'l-mâzî ve'l-hâdır ve tetallu'ât”. Fuâd Zekeriyyâ Bâhisen ve müsekkafen ve nâkiden: Kitâbun tizkârîyyun. ed. 'Abdullah Ömer. 285-321. Kuveyt: Câmi'atu Kuveyt, 1998. 
Subhî, Ahmed Mahmûd. "el-Hikmetü'l-ilahiyye fi'l ihtilâf”. Ve Hameleha'l-insân: Makâlâtün Felsefyyetün. ed. Ahmed Mahmûd Subhî. 15-23. Beyrut: Dârü’n-nahdati'l-'arabiyye, 1997.

Subhî, Ahmed Mahmûd. “el-Kîmyâ ve Câbir b. Hayyân”. Ve Hameleha’l-insân: Makâlâtün Felsefiyyetün. ed. Ahmed Mahmûd Subhî. 231-242. Beyrut: Dârü’n-nahdati'l-‘arabiyye, 1997.

Subhî, Ahmed Mahmûd. “el-Likầ beyne'l-câlem ve'd-din”. Mecelletü Kâbire 6 (1985), 21.

Subhî, Ahmed Mahmûd. “en-Nazariyyâtu’s-siyâsiyye leda'l-firaki'l-İslâmiyyîn”. Mecelletü 'âlemi'l-fikr 2 (1993), 133-175.

Subhî, Ahmed Mahmûd. "et-Tasavvuf îcâbiyyatuhu ve selbiyyâtuhu”. Mecelletü 'âlemi'l-fikr 6/2 (1975), 15-60.

Subhî, Ahmed Mahmûd. et-Tasavouf îcâbiyyatuhu ve selbiyyâtuhu. Kâhire: Dâru’1 Macârif, 1984.

Subhî, Ahmed Mahmûd. "Felsefe: Uhtun radî‘a li'ş-şeri`a em durretün lidûdin?” Ve Hameleha'l-insân: Makâlâtün Felsefiyyetün. ed. Ahmed Mahmûd Subhî. 159-170. Beyrut: Dârü'n-nahdati'l-'arabiyye, 1997.

Subhî, Ahmed Mahmûd. Fi Felsefeti't-târîh. Kâhire: Müessesetü's-sikâfeti'lcâmiciyye, 1975.

Subhî, Ahmed Mahmûd. Fi 'ilmi kelâm dirâsetün felsefiyyetün li ârâi'l-firaki'lİslâmiyyeti fi usûli'd-dîn: Eş'ariyye. 3 Cilt. Beyrut: Dâru'n-nahdati'1'arabiyye, 1985.

Subhî, Ahmed Mahmûd. Fi 'ilmi kelâm dirâsetün felsefiyyetün li ârâi'l-firaki'lİlâmiyyeti fi usûli'd-dîn: Mu'tezile. 3 Cilt. Beyrut: Dâru'n-nahdati'l'arabiyye, 1985.

Subhî, Ahmed Mahmûd. Fi 'ilmi kelâm dirâsetün felsefiyyetün li ârâi'l-firaki'lİslâmiyyeti fi usûli'd-dîn: Zeydiyye. 3 Cilt. Beyrut: Dâru'n-nahdati'l'arabiyye, 1991.

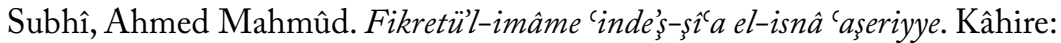
İskenderiye Üniversitesi, Yüksek Lisans Tezi, 1962.

Subhî, Ahmed Mahmûd. "Hasâisu tabi'ati't-tasavvuf”. Ve Hameleha'l-insân: Makâlâtün Felsefyyetün. ed. Ahmed Mahmûd Subhî. 94-114. Beyrut: Dârü'n-nahdati'l-‘arabiyye, 1997. 
Subhî, Ahmed Mahmûd. Hâumu ikrầ kitâbiyeh: Muhâveletün li teceddüdi'l-fikri'lİslâmiyyi. Beyrut: Dârü'n-nahdati'1-‘arabiyye, 1996.

Subhî, Ahmed Mahmûd. HelYu'iddu el-mezhebu'l-vahbâbiyye selefiyyen. İskenderiyye: y.y., 2004.

Subhî, Ahmed Mahmûd. "Heli'l-ahkâmu'l-felsefe burhâniyyetün: Dirâsetün li mevzûc et-tevfîk beyne'd-dîn ve'l-felsefe”. el-Feylesûf İbn Rüşd Müfekkiren 'Arabiyyen ve müerrihan li'l-felsefe: Buhîsun 'anbu ve dirâsâtün mehdâtü ileyh. ed. 'Âtıf el-'Irâkî. 57-88. Kâhire: el-Meclisü'l-a'la li’s-sikâfeti lücneti'l-felsefe ve'l-ictimâc, 1993.

Subhî, Ahmed Mahmûd. "Hivâr ma'a sadîk ‘ömer 'Âtıf el-'Irâkî Râiden li'lfikri'l-'akli't-tenvîrî'. 'Âtıf el-'Irâkî: Feylesûfen 'arabiyyen ve râiden li'litticâbi'l-‘akli't-tenvîrî kitâbun tizkâriyyun. ed. Fuâd Zekeriyyâ. 93-106. İskenderiyye: Dârü'l-Vefâ, 2002.

Subhî, Ahmed Mahmûd. “İbnu'l-vezîr ve difâ‘uhu 'an ehli'l-hadîs”. Mecelletü külliyyetil-âdâb 3 (1981), 203-218.

Subhî, Ahmed Mahmûd. İmâmu'l-müctehid Yahya b. Hamza ve ârâuhu'l-kelâmiyye. Kâhire: Dârü'n-nahdati'l-'arabiyye, 1990.

Subhî, Ahmed Mahmûd. "İslam Düşüncesinde Ahlâk Felsefesi”. çev. Nadim Macit. Düşünce ve Kültür Dergisi 1 (1997), 55-69.

Subhî, Ahmed Mahmûd. "İtticahâtü'l-felsefeti'l-İslâmiyye fi'l-vatani'l-‘arabi (1960-1980)”. el-Felsefetü fi'l-vatani'l-'arabiyyi'l-mu'âsır. ed. Ahmed Mâzî. Beyrut: Merkezu Dirâsâti'l-vahdeti'l-'arabi, 1987.

Subhî, Ahmed Mahmûd. “İtticahâtü'l-felsefeti'l-İslâmiyye fi'l-‘alemi'1-‘arabî fil-karni'l-'işrîn”. Ve Hameleha'l-insân: Makâlâtün Felsefiyyetün. ed. Ahmed Mahmûd Subhî. 243-270. Beyrut: Dârü'n-nahdati'1-'arabiyye, 1997.

Subhî, Ahmed Mahmûd. Makâlâtün mubtâratün fi'l-felsefeti'l-İslamiyyi. İskenderiyye: Dârü'l-Vefâ, 2001.

Subhî, Ahmed Mahmûd. "Mısru'l-kadîm ve neş'etü't-tıb”. Tevfîk Tavîl Müfekkiren 'Arabiyyen ve râiden li'l-felsefeti'l hulkiyye: Bubûsun 'anbu ve dirâsâtün mebdâtün. ed. 'Âtıf el-'Irâkî. 195-210. Kâhire: el-Hey'etü'1'âmme li şuûni'1-mutâbiic1-emîriyye, 2004.

Subhî, Ahmed Mahmûd. "Mülâbisâtü't-tasavvuf ve tabi'atuhu”. Ve Hameleha'linsân: Makâlâtün Felsefiyyetün. ed. Ahmed Mahmûd Subhî. 49-82. Beyrut: Dârün-nahdati'1-‘arabiyye, 1997. 
Subhî, Ahmed Mahmûd. "Nahvu cilm-i kelam cedîd: Dirâsetün nakdiyyetün li ba'di'l-müşkilâti'l-kilâsikiyye”. Mecelletül-cem‘iyyeti'l-mısriyye 1 (1992), 23-61.

Subhî, Ahmed Mahmûd. "Nakdu'l-mu'tezile li'l-felsefeti'1-Yûnânîyye”. Ve Hameleha'l-insân: Makâlâtün Felsefiyyetün. ed. Ahmed Mahmûd Subhî. 34-37. Beyrut: Dârü’n-nahdati'l-'arabiyye, 1997.

Subhî, Ahmed Mahmûd. Nazariyyetül-imâmiyye ledâ eş-şî́'ati'l-isnâ 'aşeriyye tablîlün felsefiyyetün li'l-‘akîde. Beyrut: Dârü’n-nahdati'l-‘arabiyye, 1991.

Subhî, Ahmed Mahmûd. Ve Hameleha'l-insân: Makâlâtün Felsefiyyetün. Beyrut: Dârü'n-nahdati'l-carabiyye, 1997.

Subhî, Ahmed Mahmûd. "Zeki Necîb ve İşkâliyyetü'l-asâle ve'l-mu'âsara”. Zeki Necip Mabmûd Müfekkiren 'Arabiyyen ve râiden li't-ticâbi'l-ilmi't-tenvîr. ed. 'Âtıf el-'Irâkî. 151-162. İskenderiyye: Dârü'l-Vefâ, 2001.

Subhî, Ahmed Mahmûd. “Âbdurrahman Bedevî: Feylesûfu'l-mütevahhid”. 'Âbdurrahman Bedevî Dirâsâtün Mehdâtün. ed. Ahmed 'Abdulhalîm 'Atiyye. 141-156. Misir: el-Hey'etü'l-câmme li kusûri’s-sikâfe, 2002.

Subhî, Ahmed Mahmûd. “'Akîdetü'l-mehdi'l-müntazır min manzûrin felsefîyyin”. Mecelletü Kâbire 81 (1988), 17-20.

Subhî, Ahmed Mahmûd - Ca`fer, Safâ Abdusselam. Fi Felsefeti'l-hadârat: elYûnâniyye, el-İslâmiyye, el-Ğarbiyye. Beyrut: Dârü'n-nahdati'l-‘arabiyye, 1999.

Subhî, Ahmed Mahmûd - Zeydân, Mahmûd Fehmî. Fi Felsefeti't-tıb. Beyrut: Dârün-nahdati'1-`arabiyye, 1993.

Suphi, Ahmet Mahmut. İslâm Düşüncesinde Ablâk Felsefesi. ed. Muammer İskenderoğlu. çev. Abdurrahman Harbi vd. İstanbul: Litera Yayıncılık, 2021.

Süt, Abdunnâsır. Mu'tezile ve Ablak $\mathcal{E}^{\circ}$ Kadı Abdülcebbar Örneği. İstanbul: İz Yayınc1lık, 2016.

Şekeroğlu, Sami. Mâtürîdî̀de Ablak E̊ Felsefî Bir Betimleme. Ankara: Ankara Okulu Yayınları, 2010.

Türkî, İbrahim Muhammed. Fi'l-fikri'l-İslâmîl-mu'âsır: Makâlâtün Tizkâriyyetün. b.y.: Dâru'l-kütübi'l-kânûniyye, 2009.

Yunus, Hişâm Hüseyin. Âliyâtül-‘almeneti ve betru'z-zâti’l-insâniyye. Beyrut: Beyrut Üniversitesi, Doktora Tezi, 2002. 